\title{
Metastatic Peripheral Primitive Neuroectodermal Tumor of Bone
}

National Cancer Institute

\section{Source}

National Cancer Institute. Metastatic Peripheral Primitive Neuroectodermal Tumor of

Bone. NCl Thesaurus. Code C36074.

A small round cell tumor of the bone with neural differentiation which has spread from its original site of growth to another anatomic site. 